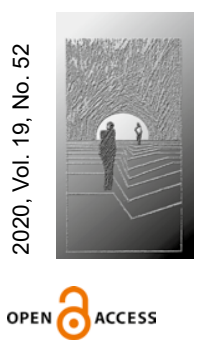

Joanna Wrótniak

http://orcid.org/0000-0002-0492-4396 Uniwersytet Marii Curie-Skłodowskiej w Lublinie Wydział Pedagogiki i Psychologii Instytut Pedagogiki

joanna.wrotniak@poczta.umcs.lublin.pl DOI: $10.35765 / h w .1863$

\title{
Samotność młodych ludzi w opinii studentów
}

Na samotność bowiem skazują człowieka nie wrogowie, lecz przyjaciele.

(Milan Kundera)

\section{STRESZCZENIE}

CEL NAUKOWY: Celem artykułu jest poznanie opinii studentów na temat zjawiska samotności wśród młodzieży.

PROBLEMY I METODY BADAWCZE: Poruszany $w$ tekście problem zawiera się w pytaniu: jakie opinie na temat samotności młodych ludzi mają badani studenci? Wykorzystana została metoda sondażu diagnostycznego (technika ankiety) oraz analiza i synteza literatury przedmiotu.

PROCES WYWODU: W pierwszej części artykułu przedstawiono teoretyczne rozważania nad problematyką samotności, zaś w części drugiej poddano analizie opinie badanych studentów dotyczące m.in.: rozumienia samotności, przyczyn występowania tego problemu oraz sposobów radzenia sobie z samotnością.

WYNIKI ANALIZY NAUKOWEJ: Samotność postrzegana jest najczęściej jako stan nieprzyjemny, uciążliwy stan pustki negatywnie oddziałujący na życie człowieka. Za przyczyny samotności młodzieży uznano: rozwój nowych technologii, dysfunkcje w środowisku rodzinnym oraz specyficzne dyspozycje osobowościowe jednostki. Wśród możliwości radzenia sobie z samotnością badani wskazywali sposoby zarówno korzystne dla rozwoju indywidualnego i społecznego, jak też niekorzystne.

WNIOSKI, INNOWACJE, REKOMENDACJE: Z badań wynika, że samotność odczuwana przez młodych ludzi staje się dziś normą i wymaga od nich podejmowania swoistej gry ukierunkowanej na wypełnienie pustki. W związku z powyższym konieczne jest podejmowanie odpowiedzialnych działań na rzecz profilaktyki samotności młodych ludzi w tłumie. Ważne jest uświadomienie rodzicom znaczenia ich autentycznej obecności przy dzieciach, okazywanie wsparcia dzieciom i budowanie właściwej więzi. Istotne znaczenie w przeciwdziałaniu samotności młodzieży mają oddziaływania i postawy nauczycieli. Ich rolą jest wspieranie rozwoju wychowanków oraz tworzenie klimatu wzajemnej akceptacji i pomocy.

$\rightarrow$ SŁOWA KLUCZOWE: SAMOTNOŚĆ, SAMOTNOŚĆ MŁODZIEŻY, SAMOTNOŚĆ STUDENTÓW 


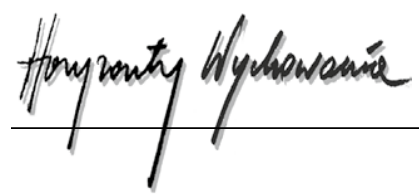

ABSTRACT

Loneliness in Young People as Perceived by Students

RESEARCH OBJECTIVE: The aim of this paper is to recognise students' views on the phenomenon of loneliness among young people.

THE RESEARCH PROBLEMS AND METHODS: The problem addressed in the text is contained in the question: What are the views on loneliness in young people held by the surveyed students? The diagnostic survey method (the questionnaire technique), as well as an analysis and synthesis of the literature on the subject, were used.

THE PROCESS OF ARGUMENTATION: The first part of the paper presents theoretical considerations on the problem of loneliness, while the second part analyses the opinions of the surveyed students concerning, among other things, their understanding of loneliness, the reasons for this problem, and ways of dealing with loneliness.

RESEARCH RESULTS: Loneliness is most often perceived as an unpleasant condition, an oppressive state of emptiness, negatively affecting human life. The development of new technologies, dysfunctions in the family environment and specific personality dispositions in the individual, were identified as the causes of loneliness among young people. Among the possibilities for coping with loneliness, the respondents indicated ways beneficial for both individual and social development and unfavourable ones.

CONCLUSIONS, INNOVATIONS, AND RECOMMENDATIONS: The research shows that the loneliness experienced by young people is becoming the norm today, and requires them to take up special stratagems aimed at filling the void. Therefore, it is necessary to take responsible actions to prevent young people's being "lonely in a crowd." It is important to make parents aware of the importance of their genuine presence with their offspring, to show support for their children, and to build a proper bond. The influence and attitudes of teachers are important in counteracting the loneliness of young people. Their role is to support the development of their pupils, and creating a climate of mutual acceptance and help.

\section{$\rightarrow$ KEYWORDS: LONELINESS, LONELINESS IN YOUNG PEOPLE, LONELINESS OF STUDENTS}

\section{Wstęp}

Samotność w obecnych czasach jest zjawiskiem powszechnym, odczuwają ją wszyscy niezależnie od wieku i statusu społecznego, występuje w znacznym stopniu wśród dzieci i młodzieży, może się przyczyniać do pozytywnych zmian zachodzących w osobowości jednostki, zwłaszcza samotność celowa. Nieumiejętność odnalezienia się w samotności tworzy z niej nośnik przykrych przeżyć, często implikujących smutek, żal, niepokój, lęk, wrogość oraz agresję (Chałas, 2005, s. 52-54). 
Badania nad problematyką samotności oraz jej wpływem na jednostkę częściej dotyczą osób dorosłych i starszych (por. Dubas, 2000; Twardowska-Rajewska, 2005; Wrótniak, 2015; 2020). Rzadziej badania prowadzone są wśród dzieci i młodzieży, choć to właśnie młodzież jest szczególnie predestynowana do przeżywania różnych postaci samotności (por. Rembowski, 1992; Dołęga, 2003; Chałas, 2003; Wasilewska, 2010; Wrótniak, 2018a; 2018b). Ze względu na specyfikę okresu rozwojowego, w jakim znajduje się młodzież, samotność i jej doświadczanie wpisane jest w tę fazę. W okresie tym łatwo o zagubienie się w wirze aksjologicznych alternatyw, o utratę pewności wobec tego, co jeszcze wczoraj stanowiło życiowy imperatyw. Ważnym celem życia staje się z jednej strony relacja oparta na intymności, która chroni człowieka przed samotnością, z drugiej zaś pokusa projektowania własnej drogi i fundamentalnego poczucia niezależności czy odrębności (Kleszcz i Łączyk, 2012; Graboś-Złotek, 2013). Zdaniem niektórych badaczy, doświadczanie samotności, szczególnie w okresie dzieciństwa i młodości, może stanowić predykator poważnych problemów przystosowawczych i osobistych. Osoby, które czują się samotne, odrzucone, częściej doznają niepowodzeń szkolnych, są zagrożone uzależnieniami czy przestępczością (Dołęga, 2003, s. 81).

W świetle powyższego szczególnie zasadne wydaje się pochylenie nad problematyką samotności młodej generacji.

\section{Metody badawcze}

Problem główny niniejszego opracowania zawierał się w pytaniu: jakie opinie na temat samotności młodych ludzi mają badani studenci? Z tak sformułowanego problemu głównego wynikają następujące problemy szczegółowe:

1. Jak rozumieją pojęcie samotność badani studenci?

2. Jak opisują osoby samotne badani studenci?

3. Jakie przyczyny samotności wśród młodych ludzi dostrzegają badani studenci?

4. Jakie sposoby radzenia sobie z samotnością wśród młodych ludzi wskazują badani studenci?

W badaniach posłużono się metodą sondażu diagnostycznego. Materiał empiryczny zebrano, wykorzystując kwestionariusz ankiety własnej konstrukcji opatrzony kafeterią otwartą i półotwartą oraz analizę i syntezę literatury przedmiotu (Łobocki, 2011, s. 247248; Pilch i Bauman, 2010, s. 79-82; 160-161). Ogółem badaniami objęto 110 studentów pedagogiki. Wiek badanych mieścił się w przedziale od 19 do 24 lat. Prawie wszystkie badane osoby to kobiety $(96,4 \%)$. W grupie badanych znalazło się jedynie 4 mężczyzn.

\section{Samotność - istota zjawiska}

Autorzy zajmujący się problematyką samotności podkreślają złożoność tego stanu, który można rozpatrywać z różnych punktów widzenia (filozoficznego, psychologicznego, 


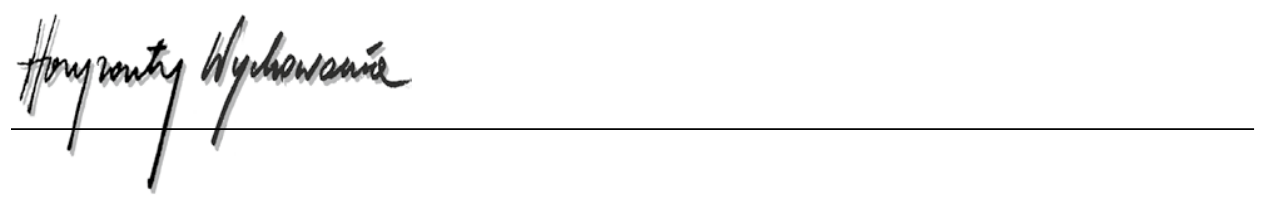

socjologicznego, pedagogicznego i innych) (por. Gajda, 1987; Rembowski, 1992; Pawłowska i Jundziłł, 2000; Dołęga, 2003; Chałas, 2005; Domeracki i Tyburski, 2006).

Samotność nie ma jednoznacznej definicji, mimo że jest powszechnie uważana za wewnętrzne uczucie, subiektywny odpowiednik obiektywnej miary izolacji społecznej lub antytezy do wsparcia społecznego. Samotność może być opisana jako postrzegane pozbawienie społecznego kontaktu, brak ludzi dostępnych lub chcących podzielić się społecznym i emocjonalnym stanem, to rozbieżność między rzeczywistą i pożądaną interakcją z innymi (Victor, Scambler, Bond i Bowling, 2000).

W Słowniku języka polskiego zjawisko to zostało zdefiniowane jako: „życie, przebywanie w odosobnieniu, brak towarzystwa, rodziny; bycie samotnym. Uczucie samotności. Samotność kogoś męczy, dokucza komuś. Lękać się, obawiać się samotności. Przywyknąć do samotności. Szukać samotności. Przeżywać coś, cierpiąc w samotności" (za: Wasilewska, 2010, s. 8).

W prezentowanym opracowaniu przyjęto definicję samotności Józefa Rembowskiego. Według autora samotność jest złożonym wielowymiarowym, psychospołecznym doświadczeniem jednostki, występującym pod różną postacią i ze złożonym natężeniem. Jest to nieprzyjemne uczucie, pojawiające się na skutek niezgodności pomiędzy oczekiwaniami a realnymi możliwościami. Należy do stanów emocjonalnych, w których jednostka jest świadoma izolacji od innych osób i niemożności działania na ich korzyść (Rembowski, 1992, s. 33).

Zdaniem Zofii Dołęgi (2019) nie jest oczywiste, kto przeżywa samotność. Nie widzimy tego, to jest stan subiektywny, wewnętrzny, słabo się wyrażający, pokazujący się jakby pośrednio poprzez zachowania, które są dla nas zastanawiające.

Według Waldemara Kozłowskiego (1996, s. 19) samotność odnosi się do naszego stanu psychicznego, jest doświadczeniem subiektywnym. Można się czuć samotnym, będąc wśród ludzi, nawet bardzo bliskich. Bywa także odwrotnie: nie mając ludzi wokół siebie, można nie odczuwać samotności.

W okresie dorastania istnieje bowiem silne dążenie do nawiązywania związków przyjaźni, relacji prospołecznych i wówczas samotność jest zjawiskiem ocenianym negatywnie; jednocześnie jednak rośnie, wynikająca z uwarunkowań rozwoju jednostki, potrzeba izolacji i odseparowania się od otoczenia. Stan kontrolowanej samotności pozwala młodym ludziom na autoanalizę oraz refleksję nad światem (por. Brzezińska, Appelt i Ziółkowska, 2016; Dołęga, 2003; Chałas, 2003). Samotność w ujęciu negatywnym jest nośnikiem przykrych doznań i przeżyć, łączy się ją z poczuciem niespełnienia, niepokojem, lękiem czy niepewnością. W aspekcie pozytywnym podkreśla się odczuwanie radości samotnego życia. Wiąże się ją z poczuciem wewnętrznego ukojenia.

Wielu badaczy wskazuje na istnienie dwóch znaczących rodzajów samotności, tj. emocjonalnej i społecznej (por. Weiss, 1989; Rembowski, 1992; Kozłowski, 1996; Dołęga, 2003). Katarzyna Maria Wasilewska (2010, s. 28-31) wyodrębnia trzy rodzaje samotności młodzieży, tj. społeczną, emocjonalną i aksjonormatywną. Samotność społeczna (fizyczna) rozumiana jest jako sytuacja niemożności nawiązania właściwych relacji interpersonalnych, co w konsekwencji prowadzić może do izolacji i zaniku więzi 
społecznej. Samotność emocjonalna (psychiczna) jest osobistym, wewnętrznym przeżyciem człowieka, to stan deprywacji potrzeby bliskości z drugim człowiekiem, co powodować może niezaspokojenie innych potrzeb psychicznych. Samotność aksjonormatywna (moralna) to sytuacja niemocy skonstruowania własnego systemu wartości opierającego się na aprobowanych normach społecznych, skutkiem czego jest pustka moralna oraz zagubienie tożsamościowe i egzystencjalne jednostki.

Pochodzenie poczucia samotności można wyjaśnić na gruncie trzech podstawowych teorii: interpersonalnej, instynktów, egzystencjalnej (Dołęga, 2003, s. 27). W świetle teorii interpersonalnej czynnikiem wpływającym na pojawienie się samotności jest brak „wartościowej komunikacji interpersonalnej" oraz brak dostrzegania i potwierdzenia znaczenia swoich relacji z innymi ludźmi. Według teorii instynktów, człowiek odczuwający samotność doznaje cierpienia związanego z brakiem przyjemności i adaptacji, w efekcie pojawia się samotność biopsychiczna. Teoria egzystencjalna dowodzi, że samotność powstaje wówczas, gdy zostają zakłócone relacje jednostki z nią samą.

W dzieciństwie na samotność może mieć wpływ fizyczna nieobecność rodziców. Dla dziecka traumatycznym przeżyciem jest zagubienie się w tłumie obcych ludzi. Tego rodzaju czynniki silnie oddziałują na jego psychikę, sprawiając, że staje się ono nieufne i zalęknione. W okresie dorastania często poczucie samotności spowodowane jest psychicznym oddaleniem od rodziców. Brak zainteresowania dorosłych, niemających empatycznego wglądu w sprawy młodego człowieka, owocują jego zamknięciem się w sobie, izolacją społeczną, często powodując niepokój, czy nawet agresję i bunt (Łopatkowa, 1983, s. 15-32). Deficyt opieki, wsparcia i miłości, doznawany zwłaszcza w okresach rozwoju (w tym również w okresie adolescencji), naraża człowieka na samotność, a co więcej, na wypracowanie trwałego nastawienia na jej doświadczanie (Kleszcz i Łączyk, 2012).

Wraz z rozwojem społeczno-kulturowym i cywilizacyjnym zjawisko samotności wzbogaca się o nowe źródła i przyczyny. Do najczęstszych przyczyn poczucia samotności obecnie zalicza się: powierzchowność kontaktów spowodowaną komputeryzacją, manipulację przez mass media, relatywizację uniwersalnych wartości, zbyt wczesne wkraczanie w życie dorosłe, rywalizację czy zatracenie korzeni kulturowych (Jakubowska, 2004, s. 83).

W literaturze najczęściej wskazuje się następujące grupy przyczyn samotności:

1. Przyczyny zewnętrzne - cywilizacyjne: rozwój techniki alienujący człowieka, nadmierna urbanizacja i uprzemysłowienie, narzucenie pewnych modeli i stylów życia, tj. konsumpcjonizm, konkurencja, rywalizacja, nastawienie na sukces, indywidualizm, racjonalność nauki.

2. Przyczyny zewnętrzne - środowiskowe: koncentrują się na najbliższym otoczeniu życia człowieka. Istotne są tu przede wszystkim relacje rodzinne, szczególnie postawy rodziców; relacje pozarodzinne typu koleżeństwo i przyjaźń. Badania Magdaleny Jakuty (2012) potwierdzają, że na pojawienie się samotności wpływ mają głównie czynniki tkwiące w rodzinie, tj. brak ustalonych zasad i norm w rodzinie, niewłaściwa w niej atmosfera, brak poczucia stabilności, niektóre wydarzenia, np. rozwód rodziców, odrzucenie grupy rówieśniczej, a także niewystarczające kompetencje społeczne oraz trudności w nawiązywaniu relacji społecznych. 


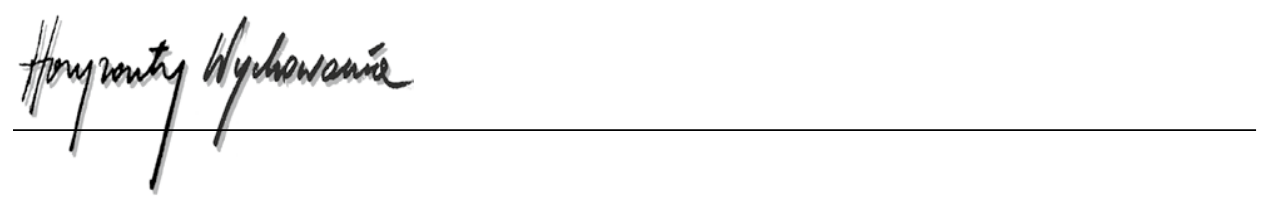

3. Przyczyny wewnętrzne (osobowościowe) - destrukcyjne tendencje i cechy osobowościowe młodzieży, takie jak: pesymizm, apatyczność, bierność, egoizm, lękliwość, koncentracja na sobie samym, labilność emocjonalna. Przyczyny te ujawniają trudności w określaniu celów życiowych i sensu życia, zaburzają samoocenę.

4. Przyczyny ontologiczne: człowiek ze swej natury pełen jest dychotomii i paradoksów egzystencjalnych, zawieszony pomiędzy potrzebą zachowania swej niepowtarzalnej indywidualności a potrzebą przynależności do grupy. Życie ludzkie przypomina swoisty dramat rozdarcia pomiędzy marzeniami o ideach a niemożnością ich osiągnięcia. Z tego punktu widzenia człowiek już jest skazany na samotność. Jest ona immanentną cechą ludzkiej egzystencji (por. Dubas, 2006; Ruszkiewicz, 2008).

Tony Lake (1993) podkreśla, iż samotność powinna być traktowana jako ważny czynnik mogący destrukcyjnie wpływać na osobowość. Może zaburzać funkcjonowanie osobiste i interpersonalne. Osoby odczuwające wysokie poczucie samotności przejawiają niski stopień stabilności zachowania, mają trudności w należytym zaspokojeniu podstawowych potrzeb: akceptacji, zrozumienia, afiliacji, wyrażania uczuć. Podkreślane są m.in. zależności zachodzące między samotnością a nieśmiałością, depresją, zagrożeniem uzależnieniami, agresją (Rembowski, 1992; Dołęga, 2003; Rębisz, Sikora, Smoleń-Rębisz, 2016). Dyskomfort i negatywny afekt związany z byciem samemu może być tak silny i chroniczny, że przybiera postać klinicznie zdefiniowanej depresji (Erozkan, 2011).

Długotrwałe poczucie samotności u młodzieży może powodować zaburzenia zdrowia psychicznego, przyczyniać się do powstania różnych negatywnych zjawisk o charakterze psychologicznym i społecznym, w tym depresji, stresu czy zaburzeń w odżywianiu (Dołęga, 2006). Wśród innych zaburzeń współwystępujących z samotnością wymienia się np. zaburzenia osobowości (zależnej, borderline), psychozy, tendencje (ideacje) samobójcze, nadużywanie substancji psychoaktywnych (Ernst i Cacioppo, 1999).

\section{Wyniki analizy naukowej}

W toku realizacji przyjętego programu badawczego zebrano materiał empiryczny, dzięki któremu stało się możliwe udzielenie odpowiedzi na postawione pytania. Odpowiadając na pytanie: „Czym jest dla Ciebie samotność?”, tylko jedna badana osoba, przedstawia samotność w świetle korzyści, samotność jest sposobem na życie, do którego się przyzwyczaiłam i teraz czerpię z niej radość.

Niemal wszyscy badani zwracali uwagę głównie na negatywny aspekt samotności. Ich wypowiedzi pogrupowano na kilka kategorii. Szczegółowe informacje zamieszczono poniżej. Według 52,7\% badanych studentów samotność ujmowana jest jako stan, w którym brakuje człowiekowi bliskiej osoby, z którą można porozmawiać, która nas wysłucha, wesprze i zrozumie. Poniżej zamieszczono przykłady tego rodzaju wypowiedzi badanych: 
- dla mnie samotność jest stanem, który kojarzy mi się z brakiem osoby, która nas zrozumie, wspiera, ale to również brak osoby, której można by powiedzieć, jak minął dzień;

- samotność jest dla mnie stanem, kiedy człowiek jest sam. Nie ma obok siebie osoby, z którą może porozmawiać, wyżalić się lub po prostu przytulić;

- samotność to brak obecności osób bliskich lub o podobnych zainteresowaniach. Respondenci, określając samotność, zwrócili również uwagę na odczuwanie jej mimo obecności innych osób, określając ją jako brak zrozumienia i akceptacji ze strony otoczenia, poczucie niedopasowania, odmienność, odizolowanie, inność (33,6\%). Kilka wypowiedzi badanych zamieszczono poniżej:

- uczucie odosobnienia, niezrozumienia, odsunięcia od grupy, inność, która nie jest przez innych akceptowana;

- samotność jest stanem emocjonalnym - nieprzyjemnym. Możemy mieć wiele osób wokół siebie - znajomych, przyjaciół, a w środku czuć się samotnym. Dla mnie samotność jest czymś więcej niż brakiem towarzystwa innych osób;

- samotność jest to uciążliwy stan pustki, brak silniejszych relacji nawet gdy otaczają nas ludzie. Poczucie bycia niezrozumianym i/lub nielubianym, odizolowanym od społeczeństwa.

Samotność jako uczucie negatywne, smutne, trudne, ciężkie określiło 12,7\% badanych, wskazując, że:

- samotność to stan, który sprawia, że człowiek czuje się nieszczęśliwy, smutny, niezrozumiany przez innych;

- samotność jest otchłanią rozpaczy, to jedno z najgorszych uczuć;

- uczucie/stan pustki w sobie, której często nawet inni ludzie (łącznie z tymi ważnymi) nie są w stanie zapełnić, łączy się to z głębokim smutkiem oraz rozczarowaniem.

Powyższą analizę ujmowania samotności potwierdzają badania przeprowadzone przez Zofię Dołęgę (1997), z których wynika, że samotność młodzieży jest subiektywnym doświadczeniem, a nie synonimem obiektywnej izolacji. W świadomości społecznej oraz w obiegu naukowym „zadomowił się” negatywny sposób rozumienia samotności. Bierze się on m.in. z relacji osób samotnych, które doświadczają swojej samotności jako stanu subiektywnie przykrego, któremu towarzyszy m.in. lęk, smutek, przygnębienie, poczucie nieszczęścia, wewnętrznej pustki, beznadziei, przeświadczenie, że jest się bezwartościowym i nieakceptowanym (Booth, 1996).

Na pytanie, czy wśród kolegów/koleżanek zauważasz osoby samotne?, na 110 badanych aż 96 respondentów (87,3\%) odpowiedziało twierdząco. Po czym poznajesz, że ktoś może czuć się samotny (jak te osoby funkcjonują)? - tu badani najczęściej, tj. 83,6\%, opisywali osoby samotne jako małomówne, smutne, zamyślone, wyizolowane. Poniżej zamieszczono kilka wypowiedzi badanych:

- osoby samotne siedzą z boku, nie nawiązują rozmowy, są smutne, żyją w swoim świecie;

- oddalone od grupy, smutne na twarzy, brakuje im kolegów do rozmów, siedzą same w kącie, nieśmiałe, brakuje im aktywności, odczuwają strach przed odezwaniem się; 


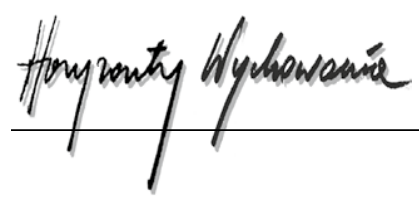

- izolują się od innych ludzi, są smutne, wycofane, uzależnione od różnych rzeczy, ale też są agresywne, nie mają przyjaciół.

Według $16,4 \%$ badanych osoby samotne to takie, które potrafią ukrywać swoją samotność, zakładają maskę i się uśmiechają. Poniżej zamieszczono wypowiedzi potwierdzające:

- są dwa typy - osoby, które mają wiele znajomych, ale nie przyjaciół, które zakładają uśmiech jako maskę, oraz osoby, które się izolują od innych, są nieśmiałe;

- osoby samotne to osoby, które najczęściej się śmieją, uśmiechają i żartują. Czasem widać przebłyski - zmiany w ich mimice, kiedy myślą, że nikt nie patrzy.

Zapytano respondentów, czy ich zdaniem odczuwanie samotności jest normą wśród młodych ludzi, czy raczej „czymś nienaturalnym”. Większość badanych, tj. 65,5\%, opowiedziała się za stanowiskiem, iż odczuwanie samotności jest normą. 49\% badanych uzasadniało swoje stanowisko, głównie odwołując się do świata wirtualnego, Internetu, mediów i ich wpływu na osłabienie relacji międzyludzkich, zanikanie relacji bezpośrednich face to face. Badani podkreślali, iż wpływ na ten stan mają również problemy, z jakimi młodzi ludzie sobie nie radzą w obecnych czasach. Poniżej zamieszczono przykłady takich wypowiedzi.

Samotność jest normą:

- ponieważ każdy ma swoje problemy, z którymi nie jest w stanie sobie poradzić oraz wpływ Internetu, który z pozoru daje nam radość, ale zagłębiająca się w nim młodzież staje się samotna;

- coraz więcej ludzi myśli egoistycznie, spędza czas w Internecie, ludzie się od siebie oddalają, częściej rozmawiają za pomocą komunikatorów;

- ludzie są zamknięci na drugiego człowieka i budują relacje w świecie wirtualnym. W opinii 16,4\% badanych samotność jest normą, ponieważ odpowiedzialność za ten stan ponoszą inni ludzie, którym w obecnych czasach jest trudno zaufać, świat jest niepewny, niebezpieczny, nieprzewidywalny. Poniżej przedstawiono kilka przykładów:

- samotność jest normą, ponieważ trudno jest zaufać ludziom, światu;

- ciężko młodym ludziom znaleźć zrozumienie czy to u starszych, czy u osób w podobnym wieku. W dzisiejszych czasach nie jest dobrze okazywać otwarcie swoje emocje. Młodzi ludzie często podejmują „grę" w ukrywanie ich;

- relacje między ludźmi ulegają degradacji.

Zdaniem 34,5\% badanych samotność wśród młodych ludzi jest „czymś nienaturalnym”. Młodość jest okresem beztroski, właściwym momentem na nawiązywanie znajomości, przyjaźni, co potwierdzają poniższe wypowiedzi:

- człowiek jest istotą społeczną i do prawidłowego funkcjonowania i rozwoju potrzebuje drugiej osoby;

- każdy młody człowiek potrzebuje bliskości czy to ze strony rodziców, czy przyjaciół,

- w tym wieku każdy powinien mieć mnóstwo znajomych, z którymi spędzałby wolny czas, korzystał z życia, tworzył wspomnienia, był radosny.

Zapytano respondentów, jakie ich zdaniem czynniki szczególnie sprzyjają odczuwaniu samotności przez młodych ludzi. Niemal wszystkie badane osoby (93,6\%) wskazały Internet i nieograniczony do niego dostęp jako czynnik decydujący. Wśród innych czynników znalazły się również m.in.: pośpiech dorosłych, brak czasu, niepewność jutra, brak 
zaufania do innych, pogoń dorosłych za karierą i pieniędzmi. Stanowisko to potwierdzają poniższe przykłady wypowiedzi:

- zanikają prawdziwe relacje, dominują kontakty online, zamykamy się w czterech ścianach z telefonem w ręku lub przed monitorem komputera;

- media kreują wizerunek młodej osoby;

- skupiamy się na karierze, pracy, pieniądzach, nie dbamy o siebie wzajemnie.

Tylko 6,4\% badanych było odmiennego zdania, uzasadniając, że:

- obecnie jest wiele możliwości, grup społecznych, kół, do których można się dopasować i kogoś poznać;

- $w$ dzisiejszych czasach jest dużo sposobów na poznawanie ludzi, każdy może znaleźć kogoś z kim będzie się dobrze czuł;

- w różny sposób możemy temu zaradzić.

Kolejne pytanie skierowane do badanych dotyczyło przyczyn samotności. Wszyscy badani wskazywali na dwie grupy przyczyn, tj. wewnętrzne oraz zewnętrzne. Do przyczyn wewnętrznych respondenci zaliczali m.in.: niską samoocenę, nieśmiałość, zamykanie się w sobie, brak zainteresowań, egocentryzm, kompleksy, niezaradność życiową, odmienny wygląd, strach przed odrzuceniem, brak zrozumienia czy otwartości na nowe kontakty. Wśród przyczyn zewnętrznych (środowiskowych) respondenci wskazywali m.in.: czynniki tkwiące w rodzinie, tj. problemy w domu, ciężką sytuację rodzinną, śmierć bliskiej osoby, alkohol w rodzinie, przemoc, niewłaściwy styl wychowania. Wśród przyczyn zewnętrznych (cywilizacyjnych) znalazły się m.in.: postęp technologiczny, wpływ mediów społecznościowych, szybki styl życia, brak odpowiednich wzorców, nadmierne spędzanie czasu w świecie wirtualnym, uzależnienia. Przykładowe wypowiedzi badanych dotyczące przyczyn samotności zamieszczono poniżej:

- brak akceptacji ze strony rówieśników - inne zainteresowania, inny wygląd, śmierć bliskiej osoby;

- uczucie niedopasowania do grupy, zaniżona samoocena, problemy emocjonalne i zdrowotne; brak pewności siebie, nieśmiałość, wstydliwość;

- brak umiejętności interpersonalnych, brak chęci do nawiązywania kontaktu z drugą osobą, zbyt częste spędzanie czasu w sieci.

Analiza wypowiedzi respondentów dotycząca wskazania przyczyn samotności młodych ludzi koresponduje z badaniami Katarzyny Wasilewskiej-Ostrowskiej (2013), która analizowała fora internetowe pod kątem odczuwanej przez młodzież samotności emocjonalnej. Badania autorki ujawniły, iż najczęstszą przyczyną samotności jest brak bliskiej osoby (rówieśnika, przyjaciela), brak zrozumienia i wsparcia ze strony dorosłych, przeobrażenia społeczne i nowa „filozofia życia”, w której dominuje zasada „mieć” nad „być” oraz cechy indywidualne, np. nieśmiałość, niska samoocena.

Ostatnie pytanie wiążące się z poznaniem opinii badanych na temat samotności dotyczyło sposobów radzenia sobie z samotnością przez młodych ludzi. Poniżej zamieszczono przykładowe wypowiedzi:

- uprawiają sport, czytają książki, oglądają filmy, piszą pamiętniki, zakładają konta na portalach; 


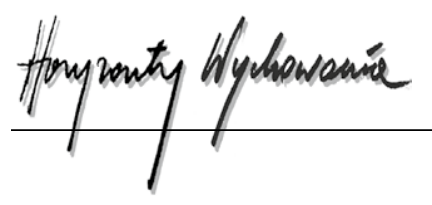

- szukają przyjaciół w Internecie, podejmują się dodatkowych zajęć, imprezują, szukają chwilowego rozwiązania w alkoholu i używkach;

- popadają w stany depresyjne, podejmują próby samobójcze, odizolowują się, uciekają w świat wirtualny.

Respondenci wymieniali zarówno te właściwe, jak i niewłaściwe sposoby, tj. czytanie książek, rozwijanie pasji, wypełnianie czasu zajęciami, nauką, pracą, nawiązywanie kontaktów z innymi przez Internet, oglądanie filmów, granie w gry komputerowe, picie alkoholu, ucieczki w uzależnienia - w świat wirtualny, wprowadzanie do swojego życia używek czy też brak umiejętności do poradzenia sobie z samotnością.

Analiza materiału badawczego uświadamia, że samotność to doświadczenie, które dla człowieka może mieć wymiar pozytywny, pozwalający zajrzeć w głąb siebie, częściej jest jednak postrzegana jako zjawisko destrukcyjne, niszczące osobę, jak również grupę społeczną. Potrzeba bliskości z drugim człowiekiem jest naturalną potrzebą każdego z nas. Chcemy kochać i być kochanymi, chcemy czuć się potrzebnymi; mamy potrzebę uznania.

\section{Wnioski i rekomendacje}

Celem podjętych badań było poznanie opinii studentów na temat zjawiska samotności wśród młodzieży. Analiza uzyskanych wyników badań pozwoliła odpowiedzieć na postawiony w tej pracy problem główny oraz problemy szczegółowe.

Analiza wypowiedzi ujawniła, że blisko 53\% badanych określiło samotność jako poczucie braku bliskości z drugą osobą, uciążliwy stan pustki. Ponad $30 \%$ badanych wskazało, iż samotność towarzyszy człowiekowi, nawet jeśli przebywa w gronie ludzi, to taki stan, w którym czujemy się niezauważeni i niedocenieni przez innych. Ponad $80 \%$ respondentów postrzega osoby samotne jako małomówne, żyjące w swoim świecie oraz wycofane. Z wypowiedzi respondentów wynika, że samotność odczuwana przez młodych ludzi staje się dziś normą i wymaga od nich podejmowania swoistej gry ukierunkowanej na wypełnienie pustki, zaistnienie w oczach innych. Można przypuszczać, że sytuacja ta może mieć związek z kryzysem wartości wśród młodzieży. Wśród możliwości radzenia sobie z samotnością badani wskazywali sposoby zarówno korzystne dla rozwoju indywidualnego i społecznego (np. nawiązywanie kontaktów, rozwijanie pasji), jak też niekorzystne (np. sięganie po używki, ucieczkę w świat w wirtualny).

Konieczne jest podejmowanie odpowiedzialnych działań na rzecz profilaktyki samotności młodych ludzi w tłumie. Ważne jest uświadomienie rodzicom znaczenia ich autentycznej obecności przy dzieciach, okazywanie wsparcia dzieciom i budowanie właściwej więzi, umożliwiającej wspólne przeżywanie zarówno dobrych, jak i trudnych chwil. Istotne znaczenie mają również oddziaływania i postawy nauczycieli, których rolą jest wspieranie w rozwoju wychowanków, m.in. traktowanie osobowo każdego wychowanka w sytuacjach edukacyjnych, okazywanie mu zaufania, wiary w jego możliwości, budowanie poczucia własnej wartości oraz tworzenie klimatu wzajemnej akceptacji, tolerancji, życzliwości i pomocy. 
Swój udział w przeciwdziałaniu samotności mają również sami młodzi ludzie, którzy powinni szanować godność własną oraz drugiego człowieka; poznawać siebie, swoje mocne i słabe strony osobowości; dbać o wszechstronny rozwój osobowy; poszukiwać płaszczyzn samorealizacji; prezentować postawy miłości, tolerancji, odpowiedzialności, troskliwości oraz szacunku. Muszą się także starać wychodzić ze strefy komfortu i podejmować trud nawiązywania kontaktów z innymi; przełamywać swoje obawy przed kontaktem z innymi; nabywać umiejętność przebywania okresowo sam na sam ze sobą w konkretnych celach i czerpać z tego stanu określone wartości; podejmować wysiłek w zrozumieniu istoty poczucia samotności; podejmować samodzielnie lub przy pomocy innych takie działania, które pozwolą usunąć poczucie samotności. Jest to możliwe poprzez budowanie i rozwijanie bliskich, pełnych akceptacji i zrozumienia relacji. Młodzi ludzie powinni dbać i pielęgnować przyjaźnie, starać się wywoływać na co dzień „efekt wioski”, tj. pielęgnować głęboko w nas zakorzenioną i na wskroś ludzką potrzebę bezpośredniej interakcji z drugim człowiekiem (por. Chałas, 2003a; Chałas, 2003b; Dołęga, 2019).

Rzeczą ważną jest stwarzanie młodym ludziom odpowiednich warunków zewnętrznych do podejmowania działań akceptowanych społecznie i promowanie takich zachowań. Pomoc młodym ludziom w konstruktywnym rozwiązaniu doświadczanych przez nich kryzysów i przezwyciężaniu samotności winna być przedmiotem szczególnych starań rodziców, opiekunów czy wychowawców.

\section{BiblogRAFIA}

Booth, R. (1996). The importance of understanding loneliness. Perspectives: A Mental Health Journal, 1, 4, 1-7.

Brzezińska, A.I., Appelt, K. i Ziółkowska, B. (2016). Psychologia rozwoju człowieka. Sopot: GWP.

Chałas, K. (2003a). Samotność a osiągnięcia edukacyjne wychowanka. W: A. Karpińska (red.), U podstaw dialogu o edukacji. Białystok: Trans Humana, 181-196.

Chałas, K. (2003b). Samotność dziecka i jej aspekty pedagogiczne. W: J. Kuźmy i J. Morbitzera (red.), Nauki pedagogiczne w teorii i praktyce edukacyjnej. Tom I. Kraków: Wydawnictwo Naukowe Akademii Pedagogicznej, 111-120.

Chałas, K. (2005). Samotność siłą kreacji osobowej wychowanka. W: E.A. Zwolińska (red.), Edukacja kreatywna. Bydgoszcz: Wydawnictwo AB, 52-56.

Dołęga, Z. (1997). Rozumienie samotności przez dzieci i młodzież. Psychologia Wychowawcza, nr 5, 436-448.

Dołęga, Z. (2003). Samotność młodzieży - analiza teoretyczna i studia empiryczne. Katowice: Wydawnictwo Uniwersytetu Śląskiego.

Dołęga, Z. (2006). Poczucie samotności wśród uczniów w kontekście spójności klasy szkolnej. W: M. John-Borys i Z. Dołęga (red.), Z badań nad zdrowiem psychicznym uczniów - wstęp do działań profilaktycznych szkoły. Katowice: Wydawnictwo Uniwersytetu Śląskiego, 69-88.

Dubas, E. (2000). Edukacja dorosłych w sytuacji samotności i osamotnienia. Łódź: Wydawnictwo Uniwersytetu Łódzkiego.

Dubas, E. (2006). Samotność - uniwersalny „temat” życia i wychowania. W: P. Domeracki i W. Tyburski (red.), Zrozumieć samotność. Studium interdyscyplinarne. Toruń: Wydawnictwo Uniwersytetu Mikołaja Kopernika, 329-349 


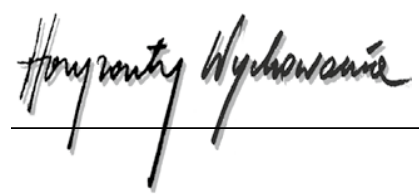

Ernst, J.M. i Cacioppo, J.T. (1999). Lonely hearts: Psychological perspective on loneliness. Applied and Preventive Psychology, 8, 1-22.

Erozkan, A. (2011). The attachment styles bases of loneliness and depression. International Journal of Psychology and Counseling, 3, 9, 186-193.

Graboś-Złotek, A. (2013), Samotność wśród dorastającej młodzieży. Problemy Opiekuńczo-Wychowawcze, nr 1, s. 45-50.

Jakubowska, L. (2004). Współczesne oblicza samotności wśród młodzieży. Kultura i Edukacja, 4. Jakuta, M. (2012). Zagubieni w tłumie - poczucie osamotnienia u współczesnej młodzieży. Resocjalizacja Polska, 3, 399-410.

Kleszcz, M. i Łączyk, M. (2012). Młodzież licealna wobec wartości, samotności i pasji. Kraków: Impuls. Kozłowski, W. (1996). Samotność i osamotnienie. Nowa Szkoła, nr 5, 19-21.

Lake, T. (1993). Samotność. Jak sobie z nią radzić. Warszawa: Wydawnictwo Książka i Wiedza.

Łobocki, M. (2011). Metody i techniki badań pedagogicznych. Kraków: Oficyna Wydawnicza „Impuls”. Łopatkowa, M. (1983). Samotność dziecka. Warszawa: WSiP.

Pawłowska, R. i Jundziłł, E. (2006). Pedagogika człowieka samotnego. Gdańsk: Gdańska Wyższa Szkoła Humanistyczna.

Pilch, T. i Bauman, T. (2010). Zasady badań pedagogicznych. Strategie ilościowe i jakościowe. Warszawa: Wydawnictwo Akademickie „Żak”.

Rembowski, J. (1992). Samotność. Gdańsk: Wydawnictwo Uniwersytetu Gdańskiego.

Rębisz, S., Sikora, I. i Smoleń-Rębisz, K. (2016). Poczucie samotności a poziom uzależnienia od internetu wśród adolescentów. Edukacja - Technika - Informatyka, 1(15), 90-98.

Ruszkiewicz, D. (2008). Życie w pojedynkę - ucieczka od rodziny czy znak naszych czasów? Łódź: Wydawnictwo Wyższej Szkoły Humanistyczno-Ekonomicznej.

Twardowska-Rajewska, J. (2005). Przeciw samotności. Poznań: Wydawnictwo Naukowe UAM.

Victor, C., Scambler, S., Bond, J. i Bowling, A. (2000). Being alone in later life: Loneliness, social isolation and living alone. Reviews in Clinical Gerontology, 10(4), 407-417.

Wasilewska, K.M. (2010). Samotność młodzieży. Bydgoszcz: Wydawnictwo Kujawsko-Pomorskie Szkoły Wyższej.

Wasilewska-Ostrowska, K. (2013). Samotność emocjonalna - jako jeden z czynników ryzyka uzależnień wśród młodzieży. Wychowanie na co Dzień, 10-11, 17-21.

Wrótniak, J. (2018a). Poczucie samotności młodzieży w dobie portali społecznościowych. Problemy Opiekuńczo-Wychowawcze, nr 8, 51-59.

Wrótniak, J. (2018b). Poczucie samotności uczniów szkoły wiejskiej. Edukacja - Technika - Informatyka, nr 3, 281-286.

Wrótniak, J. (2020). Doświadczanie samotności przez młodych dorosłych. Problemy Opiekuńczo-Wychowawcze, nr 5, 68-79.

\section{ŹRÓDŁA INTERNETOWE}

Dołęga, Z. (2019). Paradoksy samotności psychologicznej. Pozyskano z: https://www.youtube.com/ watch?v=mjBA6nRy-SY (dostęp: 27.01.2020).

\section{Copyright and License}

This article is published under the terms of the Creative Commons Attribution - NoDerivs (CC BY- ND 4.0) License http://creativecommons.org/licenses/by-nd/4.0/ 